\title{
Impact of Cash Management on Profitability in Small Manufacturing Organization
}

\author{
Dhruba Lal Pandey, Ph.D. \\ Associate professor, Central Department of Management,T.U.
}

\begin{abstract}
Small businesses are vital for economic development and employment generation. The implementation of sound cash management practices is essential to ensure the profitability. The aim of the study was to identify the impact of cash management on profitability. This study was adopted correlational research design. Purposive sampling method was adopted while undertaking research. 80 samples were considered while collecting data. The sample structure consisted of small and medium manufacturing businesses in the Kirtipur Municipality. Owners of such enterprises were taken as sample because they can better understand the cash management. Data were collected using five point Likert Scale Questionnaires. Data were analyzed using mean, correlation and regression models. Study found that Cash management has an insignificant but positive effect on profitability. It clarifies that conversion cycle, cash flow and inventory manage positively effects to the profitability but the effect is nominal.
\end{abstract}

Key words: Cash management, profitability, small manufacturing organization.

\section{Introduction}

The importance of the SEs is well recognized worldwide due to its significant contribution to gratifying various socio-economic objectives, such as higher growth of employment, output, promotion of exports and fostering entrepreneurship. Recent empirical studies showed that SMEs contribute to over $55 \%$ of GDP and over $65 \%$ of total employment in high-income countries. SMEs and informal enterprises, account for over $60 \%$ of GDP and over $70 \%$ of total employment in low-income countries, while they contribute over $95 \%$ of total employment and about $70 \%$ of GDP in middle-income countries. In the European Union countries, for example, there are some 25 million small businesses, constituting $99 \%$ of all businesses; they employ almost 95 million people, providing 55\% of total jobs in the private sector (OECD, 2015). Most of the Nepalese SMEs in Nepal are involved in processing and manufacturing of food items, consumer and household goods, and textiles and related products, both for exports as well as the domestic market. Rice, pulses, oil and flour mills, dairy, soft drinks, fruit juices and processed products, noodles, biscuits and light snack products, chocolates and candy, mineral water, dried vegetables, and some other household utilitarian and consumption goods. Other areas of SMEs' involvement include forest fiber based industries, wooden and metal handicrafts, handmade paper and products, apparels and garments, woolen carpets, pashmina shawls and rugs and leather products. SMEs' involvement is high in metal and plastic household utensils, wooden, plastic and metal furniture, printing press, polythene pipes, jute products, poultry products, livestock products, wire drawing, nail and iron rod, sheet metal, gig and black pipes, rubber tires and tubes, plywood and boards, color paint products and zinc oxide. Agro-based industries 
like tea, vegetables and horticulture products, dairy and milk products, animal husbandry and floriculture are other areas where SMEs have started to invest. Due to the opening up of investment for infrastructure development to the private sector, investment in micro hydropower and tourism resorts and complexes have also been witnessed in some regions. At the micro, cottage and family level, a sizeable number of unregistered enterprises operate on a seasonal basis (Department of Cottage and Small Industry, 2018). However, improper cash management leads to failure of SMEs. Various Researches indicate that the most crucial cause of business failure is lack of planning. Thus, sound cash management practices are essential to ensure profitability. Patel (2010) indicated that cash flow management is significant for the business profitability. The practice of basic concepts of cash flow management will assist businesses to plan for the unforeseen eventualities. One possible reason for this prevalence could be that small business owners are not equipped with cash management skills. Thus, many small business owners do not pay attention on cash management practices. The main aim of this study is to investigate the impact of cash management practices on profitability.

\section{Key indicators in cash management}

Without adequate cash flow, a firm can become technically insolvent even though assets are sufficient to manage liabilities. To reduce the chances for a firm becoming technically insolvent, the following parameters have been recommended to be employed in evaluating the effectiveness of a cash management system. This includes cash conversion cycle that is actual cash payment/expenditure for the purchase of productive/operational resources and the ultimate collection of cash from the sale of products/services. It is measured with the average time period.

Operation cash flows that is a firm generates the amount of cash in a measured time from its operation. Inventory management that is the use of EOQ, system of maintaining stock level and inventory system. Profitability that is the profitability has been measured using Return on total assets (ROTA), ROE and Net profit margin

\section{Relationship between cash management and profitability}

Pandey (2001) found that the firm may gain adequate profits, but may suffer from shortage of cash because its growing needs may be consuming cash very first so that management should look to ways of increasing cash inflows in the firm and minimizing cash outflows reducing operating expenses then the surplus cash may be managed into an investment portfolio. Saleemi (2002) found that organizations that have ineffective cash management cannot achieve desired levels of profits and these firms unfortunately will end up because of failing to achieve the said main objective. Researcher further elaborated that if cash management is properly monitored, it becomes easier to estimate profits to be generated by these firms.

Kakuru (2005), indicated that SMEs in any period was both cash receipts and cash disbursement with the net balance either a surplus or a deficit and to ensure that if cash receipts and disbursement are synchronized the management should aim at a zero balance that is to say in investing the surplus cash for profitability. Researcher further explained that if, in case of a deficit, the firm aims at increasing the cash inflows in the firm that helps to settle debts in time, reduce period for payment from its clients that increases the availability of cash in the firm. Such surplus cash can finally be invested to maximize profit.

\section{Theoretical Framework}

The growing body of empirical research examined the effect of cash management on profitability of the organization and various theories were developed in this regards. In order to examine the effect of cash management on profitability in Nepal Baumol Model Theory (1952), Miller-Orr Cash Management Model (1970) and Operating Cycle Theory has been used. Based on the stated model and theories following theoretical framework has been developed. 
Cash management

- $\quad$ Cash flow

- Inventory management

- Cash conversion cycle

Profitability

- Return on assets

- Return on equity

- $\quad$ Profit margin analysis

\section{Research Methods}

This study followed the correlational research design to examine the relationship between cash management and profitability. The population identified for this study consisted of all small and medium manufacturing businesses situated within the kirtipurmunicipality of Kathmandu. As per the record of Kirtipur Municipality, there are a total of 80 registered small and medium manufacturing businesses. Sample is considered to all those organizations. Data were collected using five point Likert scale questionnaire. For the reliability test, Cronbach's Alpha was calculated. Alpha value is .080. so, the instruments used in it is reliable enough. Correlation analysis and regression analysis have been used for the analysis. Also, ANOVA is tested for the reliability of model.

\section{Results and Findings}

Relationship between cash management and profitability and sustainability

\begin{tabular}{cccc}
\hline & Cash Management & Profitability \\
\hline Cash management & Pearson Correlation & 1 & .090 \\
& Sig ( 2-tail) & - & .427 \\
$\mathrm{~N}$ & 80 & 80 \\
Profitability Pearson Correlation & .188 & 1 \\
$\mathrm{Nig}$ ( 2-tail) & .096 & - \\
$\mathrm{N}$ & 80 & 80 \\
\hline
\end{tabular}

The correlation value between Cash management and Profitability is 0.188 and p-value is 0.096 . This result indicates that there is a low degree of positive correlation between cash management and profitability. This means as cash management increases, profitability is also expected to increase insignificantly

Impact of Cash management on profitability

\begin{tabular}{lccccc}
\hline \multirow{2}{*}{ Model } & \multicolumn{2}{c}{ Unstandardized Coefficients } & Standardized Coefficients & \multirow{2}{*}{ T } & Sig. \\
\cline { 2 - 4 } 1. (constant) & $\mathrm{B}$ & Std.Error & Beta & 3.890 & .000 \\
Cash management & 2.566 & .660 & & 1.686 & .096 \\
\hline
\end{tabular}

\section{Dependent Variable: Profitability}

The coefficients of the regressions indicate how much the net profit changes for a unit change in the predictor.So, for every unit increase in Cash management, a 0.271 unit increase in profitability was predicted, holding other variables constant. It can be seen that $\mathrm{t}=1.686<\mathrm{t}=1.96$ at $95 \%$ confidence level for cash flow management. This shows that the Cash management have an insignificant but positive effect on profitability $(\mathrm{B}=0.271$ and $\mathrm{p}$-value $=0.096)$. 
Impact of Cash management parameters on Profitability

\begin{tabular}{|c|c|c|c|c|c|}
\hline \multirow{2}{*}{ Model } & \multicolumn{2}{|c|}{ Unstandardized Coefficients } & \multirow{2}{*}{$\frac{\text { Standardized Coefficients }}{\text { Beta }}$} & \multirow{2}{*}{$\mathrm{T}$} & \multirow{2}{*}{ Sig. } \\
\hline & $\mathrm{B}$ & Std.Error & & & \\
\hline 1. (constant) & 2.213 & .703 & & 3.150 & .002 \\
\hline Cash flow & .233 & .121 & .215 & 1.924 & .058 \\
\hline Inventory Management & -.020 & .111 & -.021 & -.182 & .856 \\
\hline Cash Conversion Cycle & .189 & .126 & .167 & 1.497 & .138 \\
\hline
\end{tabular}

\section{Dependent Variable: Profitability}

The coefficients of regression that indicates how much the net profit changes for a unit change in the cash management parameters. So, for every unit increase in cash flow, a 0.233 unit increase in profitability was predicted, holding other variables constant. It can be seen that $\mathrm{t}=1.924<\mathrm{t}=1.96$ at $95 \%$ confidence level for cash flow management, $\mathrm{t}=-0.182<\mathrm{t}=1.96$ at $95 \%$ confidence level for Inventory management and $\mathrm{t}=1.497<\mathrm{t}=1.96$ at $95 \%$ confidence level for cash conversion cycle. This shows that Cash management parameters have aninsignificant effect on profitability.

\section{Discussion and Conclusion}

This study investigated the impact of cash management on profitability on small and medium manufacturing business in Kirtipur Municipality. The study arrived at the conclusion that cash management had an insignificant but positive co-relationship with profitability of small and medium size business based on the data obtained. This shows that good cash management practices slightly impact on profitability of SMEs. Mungal and Garbharran(2014) found that a significant relationship between cash management knowledge and managing cash flow. This study revealed a correlation between profitability in the business and implementation of cash management practices as wellas a correlation between the challenges of cash management practices and their ability to ensure profitability in their business. The findings of this study revealed that there is insignificant but positive correlation between profitability in the business and implementation of cash management practices. So, Implementation of cash management practices helps the business owner to improve their profitability. The findings is inconsistent with the previous findings because the owners, managers, staffs working within the small and medium manufacturing business of kirtipur municipality has low educational level and low financial status in comparison with the report analysis of previous findings. Besides that, the contextual factors are also responsible for the difference in findings. Akinyomi(2014) found that only limited studies have investigated the relationship between cash management and profitability in Nigeria. Therefore, this study examined the relationship between cash management and profitability in the Nigerian manufacturing firms. Correlation and regression analysis were carried out. The results revealed a positive and significant relationship between Cash Conversion Cycle and Return of Equity. In this research, the profitability and sustainability of small and medium businesses is found to be affected by Cash Conversion Cycle, Cash flow management, Inventory management. There is a positive but insignificant relationship between Cash Conversion Cycle and profitability. The finding is considered to be inconsistent with previous findings because proper cash conversion cycle time is maintained within the previous finding whereas that is rarely seen within study area. A buyer delays the cash payment to be done within certain period of time which directly affects to the companies as well as to the workers. So, proper conversion cycle time should be implemented for every companies to gain profit.

Therefore, it seems that poor cash management practices are a contributing factor for low profitability in SMEs. This study established the thesis that acquisition of knowledge of cash management practices was one of the important elements in the success of a small business. 


\section{Future Research Implication}

This study focused on small and medium manufacturing businesses in Kirtipur municipality. Future research can be undertaken among the businesses in other parts of Kathmandu or Nepal as a whole. Further researchers can make the comparison how this cash management is influencing the financial performance of developing or developed areas.As is evident from this study, the independent variables studied do not fully determine the outcome of the dependent variable. It will be important to carry out other studies to identify other factors that relate to profitability other than cash flow. Further research is needed to be carried out on the effect of other factors like; product/services quality, motivation among others on survival of businesses. Future research can also be carried out using different methodology, tools and techniques

\section{References}

Abdifatah, L.M. (2010).The Impact of Cash Management on Cash Holdings: A Quantitative Study of Swedish Manufacturing SMEs, Mid Sweden University, Faculty of Human Sciences, and Department of Social Sciences.

Akinsulire, O. (2003). Financial Management (5thed.). Lagos: Ceemol Nigeria Limited.

Akunga,G. (2013) The Regional Programme of Enterprise Development Survey:Structure and Performance of Manufacturing in Kenya. London: Palgrave.

Aleem, M., \& Usman, A. (2017). Impact of Working Capital Management on Profitability:A Case of the Pakistan Textile Industry. Research Journal of Finance and Accounting, 8 (21), 36-40.

Ahmad, N. N. (2016). Cash Management Practices in Micro and Small Businesses in Malaysia. Journal of Education and Social Science, 4, 331-335.

Attom, B. E. (2013). Cash Management Practices by Micro and Small -Scale Enterprises at Kasoa in The Central Region of Ghana. Asian Journal of Business and Management Science, 3 (2), 1-12.

Cheatham, L., Dunn, J. P. and Carole, B. (1989).Working Capital Financing and Cash Flow in the Small Business. Journal of Business and Entrepreneurship, 2(1),1-2.

Gill, A., Biger, N., \& Mathur, N. (2010,). The Relationship Betweeen Working Capital Management And Profitability:Evidence From The United State. Business and Economics Journal, 3(6)1-9.

John, A.O. (2014). Effect of Cash Management on Profitability of Nigerian Manufacturing Firms. International Journal of Marketing and Technology, 4 (1), 129-140.

Kargi,H. (2011). Capital Regulation and Bank Risk-taking: A Note. Journal of Banking and Finance, $13,883-89$.

Kew, J. and Watson, A. (2012). Financial Accounting: An Introduction (4thed.). Cape Town: Oxford University Press.

Kakeeto, F., Micheal, T., Pastor, K., \& Osunsan, O. K. (2017). Cash Management and orgainizational Profitability in Gumutindo Coffee Cooperative Enterprise Limited (GCCE), Mable District Uganda. Journal of Research in Business and Management, 5 (5), 33-40.

Mugal, A., \& Garbharran, H. L. (2014). Cash Management Challenges of Small Business in Developing Community. Mediterrnean Journal of Social Science, 5, 11-21.

Olowe, A. (2008). Financial Management: Concepts, Financial System and Business Finance. Lagos: Brierly Jones Nigeria Limited.

Pandey, M.I. (2004). Financial Management (9thed.). New Delhi: Vikas Publication House Pvt. Ltd.

Enow, S. T., \& Kamala, P. (2016). Cash Management Practices of Small, Medium and Micro Enterprises in the Cape Metropolis, South Africa. Investment Management and Financial Innovations, 13 (1), 230-236.

Fatimah, Y. A., Biswas, W., Mazhar, I., \& Islam, M.N. (2013). Sustainable Manufacturing for Indonesian Small- and Medium-sized Enterprises (SMEs): The Case of Remanufactured alternators. Fatimah et al. Journal of Remanufacturing, 3(6),1-11.

Oluoch, J. O. (2016). The Impact of Cash Management Practices on Performance of SMEs: A Survey of 
SMEs in Eldoret Central Business District. IOSR Journal of Economics and Finance, 7 (6), 1-7.

Paul, G. D. (2015). Cash Management and Profitabilityof Small and Medium Scale Enterprises in Nigeria. International Journal of Advanced Studies in Economics and Public Sector Management, 3, 229-239.

Petrini, M., \& Pozzebon, M. (2009). Managing Sustainability with the Support of Business Intelligence: Integrating Socio-environmental Indicators and Organisational Context. Journal of Strategic Information Systems, 18,178-191.

Raymond, A.E., Adigwe, P.K., \& John-Akamelu Racheal, C. (2005). The Credit Managementon Liquidity and Profitability Positionof a Manufacturing Company in Nigeria. European Journal of Research and Reflection in Management Sciences, 3 (3), 32-48.

Smirat, B. Y. (2016). Cash Management Practices and Financial Performance of Small and Medium Enterprises (SMEs) in Jordan. Research Journal of Finance and Accounting, 7, 98-107.

Uwonda, G., \& Okello, N. (2015). Cash Flow Management and Sustainability of Small Medium Enterprises (SMEs) in Northern Uganda. International Journal of Social Science and Economics Invention, 1 (3), $1-20$.

W., M., \& Gathogo, G. (2016). Effect of Working Capital Managementon the Profitability of Manufacturing Firms in Nakuru Town, Kenya. International Journal of Economics, Commerce and Management, IV (4), 1082-1105.

Wickramasinghe, M. B., \& Gunawardane, K. (2017). Cash Flow Risk Management Practices on Sustainable Financial Performance in Sri Lanka. International Journal of Arts and Commerce, 7 (8), 57-69. 